\title{
Is Globalization leading to No space and No Choice?
}

\author{
Nikita Khanna
}

\begin{abstract}
The paper tries to highlight the reasons behind the backlash against the increasing economic and cultural reach of multinational companies. Globalization is a process whereby corporations discovered that profits lay not in making products but in creating branded identities that people adopt in their lifestyles. The other very essential argument is that there is an increasing commercial takeover of public space, destruction of consumer choice, and replacement of real jobs with temporary work. There is an assault on civic spaces, civil liberties and employment. Interestingly there is also a democratic resistance arising globally to challenge the hegemony of these brands as they have become revered symbols worldwide. The age of the brand witnesses the evolution of a new relationship between the producer and its product. Originally, brands were meant to assure the quality of the product, today the brand has detached itself from the product to become the selling point. The paper further would give various examples as highlighted by Klein in NO LOGO to analyse how corporate global marketing takes place. It would trace a shift from product marketing to brand marketing that has relegated manufacturing to a subordinate role in contemporary capitalism. The resultant would be degradation of labour, environment and human rights. It would emphasise on the condition of underpaid outsourced temporary contract labourers and further analyse the role played by women workers as globalised labourers where studies have shown these corporations having a huge female unmarried workforce. It then will highlight anti corporate activism in light of contemporary agreements in WTO, the anti WTO movement, and other trade agreements with reference to global injustice and the role played by trade and labour regulations.
\end{abstract}

\section{Introduction}

To begin with, the basic perspective is that multinational corporations have become so big that they have superseded governments and have become the ruling political bodies of our era. Unlike governments, multinational corporations are accountable only to their shareholders and there are no mechanisms in place to make them "put people before profits". According to Naomi Klein, corporate rule has been associated with an assault on the three social pillars of civic space, civil liberties and employment. These social pillars are highlighted by Klein in the book by analysing No space, No choice and No jobs. Before analysing the three pillars in detail I would highlight a very essential argument raised by Naomi Klein that is a prediction of how wages will fall for developing countries that embrace free trade today. The countries competing for the export-processing-zone, the incentives to lure investors are increasing and the wages and standards are being held hostage to the threat of departure. The argument is that entire countries are being turned into industrial slums and low-wage ghettos, with no end in sight. Though this argument might have contradictions to the argument that trade liberalization promotes economic growth and reduces poverty, but the 
argument of falling wages is essential to understand the concept of marketing brands and not products.

To further analyse the argument it is important to draw a relation of No space, No choice and No employment with branding, and how then a company becomes a place for ideas and not products.

Some interesting examples of brand creation include Nike, Starbucks, Mc Donald's, Levis, Microsoft, IBM etc. Nike established itself not as Shoe Company but as a sports company; Starbucks established itself as a community company and not as a coffee company. What was common in them was emphasis on ideas; companies transcended and then established a parallel with other brands. What emerged then post creation of ideas and not products was a celebrity culture, and with it, it was difficult to dismiss branding mania. Two major effects further explain anti corporatism that is creation of no space and no job. These brand express ideas and thus work to project as many surfaces as possible, as a resultant end company becomes about idea and not products and this kind of marketing is done by launching cultural events, magazines and other forms of marketing the brand strategies, with this the product is disappeared and a brand is left. Advertising agencies act not as marketers but as brand factories. The process though is not about advertising but production which is diminished in the global corporate industries. For example Nike when decided to be about sports it was not just organising sports events but also buying events. With this type of branding the is no gestation period for new ideas and then branding is about transcending products where people who produce the product get demotion and are lowest in the hierarchy of marketing and not manufacturing products where branding becomes an expensive enterprise and money to fuel these ambitious utopias is the production finances. Where then instead of the quality of the product the concern is to let someone else produce and the company would buy from the buyer who sells at the lowest price, with this the branding economy is turned into contracts.

To trace the historical development of this phenomenon, beginning with the shift from selling products manufactured in local factories to the marketing of brands that become identified with culture itself. Indeed, products are made while brands are sold. The shift to brand marketing began with an invasion of cultural space. Corporations became so fixated on their brands that production became secondary. In an effort to maximize funds for brand promotion, therefore, they turned to methods by which they could minimize production costs. This goal was accomplished by moving factories to third-world nations, where labor laws and minimum wages, not to mention benefits packages, were non-existent. The impact on the middle classes in developed nations has been devastating. Additional "brandizing" has been accomplished by the advent of "brand-name" stores, such as Nike Town of Disney, all meant to give a brand experience to the children and adults who patronize them. Add to this the theme parks, cruise ships, "branded towns," resorts, and the intrusion of brands into schools and colleges through huge donations in exchange for a privileged position, and one is easily able to see the complete usurpation of cultural space.

To further view how corporate global marketing takes place in a globalised era, I highlight the various reasons of WTO protests. During the anti WTO protest there arose a common cause 
was environment degradation, labour standard and human rights. Behind protests bad mood was rising against global brands since there were no enforceable regulations. There was an Ideology euphoric convention arising in ecommerce. The changed notion was to produce brands and not products, as the market was with identical products so marketing was about brands and there arose hostility towards products. This could be showcased in the fact that Nike doesn't even own a factory where labour laws could be regulated. What couldn't be ignored thus is the mechanics of branding. Though even with mechanics of branding the economies were leading to degradation with disposable temporary workforce and labour.

For instance Microsoft has outsourced labour force, the class system is not just between 1st and $3^{\text {rd }}$ world but even between companies. Brands weave way in culture but opt out of full time employment by hiring part timers and contractors. Labour activist when target these corporate firms there is a realisation of why these campaigns are not consumer campaigns but political. Citizen's battles against monopoly environment, human rights, gm crops and how it becomes a culture. The activist's juxtaposition of production and brand is in contrast of manufacturing, production and marketing with consumer selling where a product with manufacturing cost of 2 dollars is sold at 200 dollars at Nike town. There then is arrogance of branding to protect true product image where often the state police is also seen protecting these corporate towns like Nike town or for instance star bucks.

Klein's highlights an important point, that capitalism in the age of globalization is the age of brands where logos play an essential role in marketing and branding. Individuals stay in a branded world where from cultural standards to values are increasingly defined by mega brands like Nike where the representation comes with assertion of individuality. It thus witnesses a new relationship between producer and its product. To trace the historical evolution of brands it was meant to assure the quality of the product but today it has detached itself from the product to become the selling point. To further evaluate this it won't be wrong to say that many brand name multinationals are in the process of transcending the need to identify their products. Where the marketing departments are charged with the managing of brand identities where there is the direct competition with factory production. To quote a president of the branding agency where he said, 'products are made in the factory, brands are made in the mind'. It is essential for us to make a distinction between products and brands where a product is made in a factory but a brand becomes a brand when consumers have an inclination towards the product. What is essential to highlight in these arguments is a term that has been given importance in the contemporary times which is youth demographic where a visible switch is seen from selling a product to selling a lifestyle. Klein sees this as a parasitic relationship where what the brands did to cultural expressions of youth have further created youth alienation and a sense of revolt with the rise of multiculturalism. This is due to a shift from product to brand marketing that has relegated manufacturing to a subordinate role in contemporary capitalism. Because a corporation has to allocate its financial resources in a way that returns the greatest profit, it became obvious that production costs had to be reduced. The means to do this were found in third world countries, where cheap labour could be acquired, allowing, in some instances, as much as a four hundred per cent mark-up on the 
product once it returned to the developed, consumer-driven country. Nike was the first corporation to adopt this strategy.

What is problematic in this is a focus on marketing instead of manufacturing which leads to assertions that aims to transcend the driving force of corporations. If marketing becomes innovative to an extent the old contradiction arises where there is a crisis of over-production or under-consumption. It is important to understand the over production and under consumption has a relation with consumer demand. Where more corporations try to increase their profits by limiting competition there is transformation of workforce into part time temporary free lance home based workers. This means cutting the consumer demands that simulate production. What is essentially important is that this limiting demand has a direct relation with income distribution which induces over capacity. To view the example of US economy though expanded in 1990s there was a tight labour market and at the same time there was the record of low unemployment levels. It is around 1997 that the real wages had a rise after years of stagnation. The restructuring has made US economy super competitive but has a worst income distribution of income among major advanced countries. While liberalisation enabled trans-national corporations to see trade and financial liberalisation with respect to World Bank and WTO there arose a great inequality on the mass market, the number below poverty line. The culture of capitalism has seen a traceable presence in anticorporate globalization movement for e.g. Nike Adidas and wall Disney ultimately had a direct co-relation with street silicon valley complex where the crisis of over capacity in production is leading to hegemonic of finance capital. Moving forward in a time when de-regulation became public policy, corporations accomplished mergers and buyouts, driving smaller, independent businesses out. These practices have lead to multinational conglomerates which, because of their huge profits, are able to wield inordinate political power through lobbying and campaign contributions, not to mention the threat of pulling out if their demands are not met. With deregulation and the ability to control governments of third-world countries, corporations have moved in to privileged positions, not just exploiting the poor, but destroying environments and ecosystems as well.

A backlash has begun that includes "culture jamming," protests, demonstrations, the ejection of corporations from college campuses, and the exposure of corporate "dirty big secrets." As the Internet has developed, so, too have these movements grown, now able to communicate with one another, to coordinate activities, and to undermine corporations through concerted technological efforts to subvert advertising and hack into corporate websites. Executives are subject to protests, pie-throwing, and other abuses as they make public appearances. It is in these movements, small but determined that Klein sees the potential for consumers to reclaim their independence and freedom of choice, to press for human rights globally, and to take back their cultural space and identities.

To conclude with, the paper tried to trace the evolution of contemporary marketing strategies, and how it was an attempt of capitalists to save their profit-making endeavours in an age of mechanised mass production. It highlights how competitive branding and logo centred 
advertising started acquiring an important place post 1990s. This evolved age of logo is one characterised by the increasing visibility of advertising virtually everywhere from physical advertising to advertising in cyber space. The old paradigm was that all marketing was selling a product, but a change is that in the new market, the product always takes a back seat to the real product and the brand becomes the selling point. It will thus bring to our attention the conditions under which the producers of the goods have laboured, and particularly the way that their labour has produced goods whose value far exceeds what they are being paid in exchange for their labour. The paper made an attempt to analyse hoe corporate global marketing takes place and how there is a direct attack on public spaces with degradation of consumer choice and replacement of real wage jobs. It further highlighted an emerging system of global injustice where there is emerged relation of No space, No choice and No employment with branding, and how then a company becomes a place for ideas and not products by creating brand hegemony in a global sphere. 